\title{
12
}

\section{FIRE SUPPORT: 103 FIELD BATTERY ROYAL AUSTRALIAN ARTILLERY IN ACTION}

George Bindley, John Griggs, Peter Aspinall, Doug Heazlewood and Brian Mortimer

\section{Editors' introduction}

This chapter is an integration of five contributions by members of the artillery battery which directly supported 5th Battalion, the Royal Australian Regiment (5 RAR), operations in October and November 1966, 103 Field Battery of 1 Field Regiment, Royal Australian Artillery (RAA). The Vietnam War relationship between an Australian infantry battalion and its directly supporting artillery (usually a battery in support of each battalion) was extremely important for both. For the infantry, the artillery was a powerful mobile defence against an attacking enemy and an aggressive multiplier of combat power. For the artillery, their security depended partially on protective infantry, both located with their gun positions and in maintaining control of the battlefield more widely. It was very important for both sides of this partnership that they had high confidence in each other. Lives hinged on how well this mutual dependence was accepted, valued and practised.

We, 5 RAR, had had four months of working with 103 Field Battery, and they had our fullest confidence. The battery was equipped with six Italian-designed OTO Melara L5 $105 \mathrm{~mm}$ pack howitzers. These guns were compact and could be disassembled for transportation by Iroquois 
helicopter. They could be relied upon to deliver accurate fire over ranges up to 10,000 metres. They were capable of firing in the upper register (i.e. at barrel elevations of over 45 degrees), which made them particularly useful for giving support in hilly or mountainous country. They could be fired against enemy positions and his attacking or reconnoitring forces, by day or by night. One defect was that their sights could mist up in rainy weather. Another was their relative lightness of construction, which made the gun trails liable to fracture when rounds were fired at maximum charge of propellant.

Within each of our companies, 103 Battery embedded forward observer (FO) officers, each with a bombardier assistant (FO Ack), two artillery signallers and a batman - collectively known as an FO Party. The FO Parties became an integral part of each company headquarters and shared every danger and hardship, trod every weary kilometre and were, in the deepest sense, our brothers-in-arms. When the battalion was not deployed on operations they lived with our companies in the 1st Australian Task Force ( 1 ATF) base at Nui Dat, and not with their own battery - they were absolutely of our ilk.

The FO Parties, moving with each of our companies when we were out on operations, kept themselves fully in the picture with every aspect of our tactics and procedures, and learned about their many nuances - to the extent that they were able to instinctively anticipate our needs and be instantly ready to call for supporting fire from their battery's guns. The FOs also had access to more powerful firepower, delivered by US heavy artillery (155 $\mathrm{mm}$ and 8-inch guns), and even to naval gunfire from warships within range. Through coordination with US Air Force (USAF) airborne forward air controllers, the full orchestra of integrated close air support and artillery and mortar fire could play under their batons, should this level of firepower be needed. FOs were appropriately skilled and conveniently positioned - at the side of the infantry commanders in the forefront of battle.

Another integral element of our fire support was the battalion's own Mortar Platoon. The $81 \mathrm{~mm}$ mortars fired a less powerful round than the $105 \mathrm{~mm}$ guns, but they were man-portable and could be deployed in action close to the troops they were supporting. On these operations up in the hills, our Mortar Platoon rendered great service because of their high angle of fire. This meant they were not as limited as some artillery guns which required a flatter trajectory for their shells and could have 
their fire masked by some of the steep, high ridges that our infantry had to fight over. Mortars have been lobbing their bombs over crests into masked terrain for hundreds of years. Nonetheless, they could not match the destructive power of our 'nine-mile snipers'.

With that age-old, infantry-conferred and affectionate sobriquet, let us now look at the problems of fighting from the gunners' perspective. First is the view of a young lieutenant who was initially a gun position officer (GPO), in charge of the guns at the point of firing, and, later, an FO.

\section{Overview: Lieutenant John Griggs}

In subsequent paragraphs, my colleagues add touches to an artillery collage of which I apply the first layer. For our esteemed infantry brothers of 5 RAR, who so often sought our wares, we hope that our group effort will reveal much about the dark art of what is now rather ancient gunnery. Some facets may have had them wondering for more than 50 years!

To start the composition, I briefly look at activity in five different gun positions, including those we used in Operations Canberra, Robin and Queanbeyan (gun positions 3, 4 and 5), to show how we operated in each of them.

\section{Gun position 1 - Duc Thanh}

I remember this village as it was the most northerly area we occupied during my time as GPO. From Duc Thanh we could cover the northern, eastern and western approaches to Nui Dat, and give support to the individual company positions occupied during patrolling operations and village cordon and search operations through the northern half of Phuoc Tuy. From memory, Duc Thanh was occupied by people resettled from North Vietnam. It wasn't a busy time firing close support missions, but I spent a considerable time in the command post (CP), getting target records up to date. Thank heavens CP lighting, via small battery-powered fluoro tubes, had improved by the time we arrived, as all target records were written in $\mathrm{HB}$ pencil into target record books and much of that work was done at night. These included defensive fire tasks (nicknamed tin trunks) for the troops we were supporting, and counter-mortar target records. The call for the latter fire was 'Bombard' and employed six rounds per gun FFE (fire for effect) on each suspected enemy mortar position. 
'Bombard' was used powerfully during the night before the Battle of Long Tan by the whole of 1 Field Regiment, when the 1 ATF base at Nui Dat was attacked by enemy mortar fire. Each application delivered 108 rounds of HE (high explosive) $105 \mathrm{~mm}$ artillery shells onto each suspect location.

During each night, harassing and interdiction (H\&I) missions were fired, generally being one or two guns firing one or two rounds at predetermined times on tracks or targets selected by the intelligence staff. Viet Cong (VC) prisoners stated during interrogation that they feared our unpredictable H\&I fire. This was welcome feedback because the tasks were very tiring and disruptive at night for gun detachments (crews) which generally were under-manned by tired and weary gunners.

\section{Gun position 2 - Nui Dat Base}

After deployments to remote gun positions, reoccupying the 1 ATF base gun position was a time-consuming procedure. Here the battery was occupying and defending an unprotected and open approach to the Task Force headquarters (HQ) across a vast paddy field. When deployed to a gun position elsewhere, we needed to leave behind a sizeable rear detachment, thus reducing the numbers serving the guns on operations. We also did three other things: (1) set up dummy (make-believe) guns to give the impression that our base position was occupied; (2) maintained a standing patrol forward of our sector of the base's defensive wire obstacles; (3) readied the gun position for the returning guns. There were also a myriad of other tasks including preparing ammunition, unloading stores and personal gear and being ready to respond to calls for fire at all times.

\section{Gun position 3 - Ap Ong Trinh Dc}

From memory, we occupied this position during the afternoon after a road trip from Nui Dat. As I recall, the regiment's 2IC (second in command) selected the area after an air reconnaissance. Imagine my reaction later, when I found he had allocated an area for six gun platforms and a CP which was under water. From the air the water was hidden by long grass. I never forgot that episode and later as an instructor in gunnery and a battery commander I drove the lesson home to others: reconnaissance for gun positions MUST always be conducted on foot. We were quite busy in 
this position, but it was not suitable for a long stay and the commanding officer (CO), Lieutenant Colonel Richmond 'Dick' Cubis, had us move further along Route 15 a couple of days later.

Actually, on the day we moved, Cubis flew in around 1000 and chipped me for not having shaved. I told him how I had been busy and was yet to arrive at the shaving point in my morning routine. (The $\mathrm{CO}$ wasn't noted for his sense of humour.) My mornings were hectic from stand-to (the time each day, before first light, when all personnel come to an armed and fully alert status) until around 1000. My duties in changing from night to day routine included checking gun parallelism (a detailed procedure involving a theodolite to ensure that guns were aligned exactly parallel to each other), changing CP staff, giving briefings, maintaining gun records and so on. So, around 1000 was my 'birdie-bath' time, when a section commander stood in for me in the CP.

\section{Gun position 4 - Ap Ong Trinh Dp}

We moved 2 kilometres south-east into an area where we stayed for some time, in company with some larger $155 \mathrm{~mm}$ guns from Battery A, 2/35 US Artillery Battalion. Their H\&I tasks at night were purgatory for us, as we felt the full force of the blast across our gun position when they fired. The shock wave and noise would wake the dead.

While 5 RAR was busy up in the hills, we were worried somewhat by crests (simply put, where targets might not be able to be engaged because there was a hill or ridgeline in the way). However, our howitzers were able to fire at high angle (like a mortar) so, generally, we were able to answer any call for fire. The steep hilly ground did affect the fall of shot, but that's what FOs were trained to handle.

Being alongside Route 15, we inevitably attracted local vendors selling food and drinks. We also set up showers through which our soldiers were rotated, much to the delight of locals passing by in crowded buses, which slowed down to allow passengers a good look. Incoming US troops were trucked past in convoys every day for hours at a time during daylight, but it was at night when things got a bit tricky.

For whatever reason, some South Vietnamese gunners in the village of Phu My took a dislike to the area surrounding us and the area in which 5 RAR was operating. They sent more than a few rounds our way, 
apparently once too often. On one occasion Lieutenant Colonel Cubis ordered my guns to load and lay on the village. Receiving this fire mission from my CO made the hairs on the back of my neck stand. I knew the location was designated as a 'no fire zone', occupied by friendly troops and civilians. I contacted our battery captain, George Bindley, and our battery commander, Major Neville Gair, for clarification. We had our signallers try to contact the US Army advisers in the Phu My area by radio to no avail. I had two signallers carefully record all fire orders and conversations, for evidence purposes, as there would have been quite an inquiry had we fired.

We did not fire, and the circumstances in which a potential catastrophe was averted are explained later in this chapter by George Bindley. A lot can go wrong in war when coordination and liaison are not up to required standards; and a hasty, unhelpful interference in operational events by a senior commander rears its head.

The return to Nui Dat after Operation Queanbeyan saw my time as GPO of 103 Field Battery come to an end. I handed over to Lieutenant Mike Langley and joined C Company, 5 RAR, (under Major John Miller) as their FO, replacing Lieutenant Kerry Mellor.

\section{Gun position 5 - Lang Phuoc Hoa}

This was my first operation as an FO. My assistant was Bombardier Dave Rose who later worked for me as a warrant officer at the School of Artillery and rose to the rank of major. Dave and I learnt a very salutary lesson while searching the village on the edge of the Rung Sat (Special Zone) before we assaulted the island of Long Son. There were calls for illumination rounds to be fired in order to light up an area offshore. Major Miller and I were standing next to an armoured personnel carrier (APC) observing over the water, which was being lit up, when we heard a strange buzzing noise. It got louder and suddenly there was a great CLANG on the APC. The noise was made by the steel inserts or sleeves which were carried in the illumination shells, to assist in ejecting the flares and parachute without damaging them. The inserts simply fell to the ground while the empty carrier shell continued in its trajectory. The firing tables would tell where the empty carriers would fall, but there was no mention of the sleeves. The lesson we learnt was 'do not have illumination rounds burst overhead'. 
On that gun position the guns used a very effective deception plan to convince the enemy that 5 RAR was going to assault north into the hills rather than south onto the island. Just before $\mathrm{H}$ hour (the time at which an operation commences) the guns, which had been pointing north and firing H\&I in that direction during the night, suddenly turned around to face the island just as the first wave of the air-mounted assault was landing.

\section{Life as a gun section commander: Lieutenant Doug Heazlewood}

I joined 103 Field Battery after a period as assistant adjutant for the first two months of 1 Field Regiment's tour of duty in Vietnam, a role for which I felt untrained and comparatively lacking in motivation. But as a section commander in 103 Battery, I felt like Brer Rabbit safe in the briar patch - happy and comfortable in the only role for which I had in any way been fully trained.

On reflection, I may have had more reason to be daunted. 103 Battery was a team in every sense of the word, being possessed of a very dedicated group of competent and professional officers and a leavening of some of the finest non-commissioned officers (NCOs) I would ever know. Many already had a grounding in active service and went on to achieve distinguished careers. The complement of gunners included many we considered to be the pick of the regular soldiers of the regiment and about 30 or more men of the first intakes of conscripted national servicemen. Their readiness training in Australia had made them into the bestperforming team that I encountered, before or since. By the time I joined them, I could not discern any differences between regular and national service soldiers - I always had to ask whether a soldier was the one or the other. One of the 'nashos', Bombardier Graeme Sutherland, had already developed the competence and confidence to serve as a gun detachment commander during the most challenging task of our entire tour, the Battle of Long Tan.

Although I was their officer, and they ultimately would have to do what I said, I needed to be accepted into their team before my opinion was thought to matter. A vivid memory is that my first ever deployment with an artillery battery, operational or otherwise, was motoring up the 'black' route to $\mathrm{Binh} \mathrm{Ba}$ as the battery leader! 
I was also very pleased to learn that we were to become the direct support (DS) battery for 5 RAR, where I knew some of the officers. My belief then, borne out by the experience, was that they were a formidable team and we would have to perform very well to match them. I was greatly heartened, when it came time for us to 'rotate' from being their DS battery back to the general support role, that 5 RAR had made the very generous gesture of requesting that we be allowed to remain their DS battery until the end of their tour. I shared the pride, felt by everyone on the gun line, in the knowledge that we had earned their trust and gratitude.

With the help of our HQ battery comrades, we had played a leading role in fire support for the Battle of Long Tan, all on the gun line gaining some salutary lessons to be applied later in our tour. 5 RAR's first major excursion into the long-term task of clearing and establishing control over Phuoc Tuy Province came about in October. It was the series of operations described in this book that forced us to extend our capacity to overcome the unique problems of effective fire support for infantry offensive operations in very difficult terrain and at the further reaches of our allotted area of operations.

From the perspective of the gun line, the special problems brought about by the nature of these operations that we needed to meet and overcome included:

\section{Optical sights}

Constant, unpredictable instances of gunsights 'fogging up' had to be managed. Being called for a fire mission, only to find your sight suddenly fogged up, thus rendering the gun useless until it cleared, was not to be countenanced. This problem was accentuated during prolonged operations far away from the replacement or repair readily available at Nui Dat. Sergeant Reg Matheson's remedy was the preventive measure of making sure that his sight, when not on the gun, was in his bed, whether he was there or not.

\section{Unstable gun platforms}

This was especially a problem in the gun position first occupied for Operation Canberra, where the ground was so wet that we had to enlist the aid of APCs to get some guns into position. Once settled, they became very difficult to traverse through the large switches in bearing we needed 
to accommodate, with the trails burying and needing to be dug out. (The trails are the rearmost parts of the gun by which it is towed and, when in action, they 'anchor' the gun to the ground and prevent it being driven backwards when fired.) Foresight, anticipation and cooperation between gun detachments were the key elements in dealing with this problem.

\section{Gun aiming points}

The restricted size of a gun position's defensive perimeter would make it difficult to deploy gun aiming posts far enough from the gun to maintain accurate laying of the gun onto the target. We were often reduced to using paralleloscopes as the primary method of laying the guns on target, and this brought other difficulties. Innovative ways of illuminating the gunsights had to be found to accommodate the amount of night firing that was called for, and large traverses of the gun would bring the 'scope' to the 'wrong' side of the gun - very slick drills for changing and recording aiming points at night had to be perfected. The gun moving about on a soggy 'platform' added to this difficulty.

\section{Fatigue}

Gun position defensive perimeters were not fully occupied in daytime and this required the gun crews to man double sentry shifts during the day. Work required to establish and develop the gun position, the strenuous nature of engaging planned and opportunity targets and the requirement to engage in very active H\&I programs during the night combined to restrict us to about four hours sleep per day for the duration of these operations.

\section{Other hazards}

In the first gun position occupied to support Operation Canberra, we were the unhappy recipients of two incoming rounds, travelling straight towards us at high velocity, and landing as close as 200 metres outside our perimeter. This happened at regular intervals for a few days. We were slightly, but not entirely, relieved to eventually learn that they were 'friendly' - coming in error from two Army of the Republic of Vietnam (ARVN) $105 \mathrm{~mm}$ guns located in their military compound at the village of Phu My, a few kilometres north on Route 15. They were a powerful nuisance and communication difficulties led to a predicament 
which could have had calamitous results, but for the calmness of John Griggs and the initiative of George Bindley. They recount their respective dilemmas, and the actions they took, elsewhere in this chapter.

These were not the only hazards encountered in providing safe and effective fire support to 5 RAR. The possibilities for error are everpresent in the application of artillery fire anywhere. They assumed an extra dimension in the very intimate support we were usually required to provide to our infantry comrades. Knowing the accurate location of the target, as well as those of the observer and the guns, was affected by the uncertain quality of the maps. Also, we had no way of knowing whether the meteorological information we were given to allow for wind, humidity and temperature was accurate. The steep slopes encountered in the Nui Thi Vai hills, exacerbated by the variety and height of the timber covering, added to the challenges of the laws of physics. It seemed that any error arising from factors beyond our control (as opposed to 'mistakes') was magnified and had the propensity to detract from the mutual trust and confidence we strove to achieve with our infantry comrades. Inevitably, there were instances of people being wounded, killed and frightened by our fire. In my memory, on no occasion during our whole tour was anyone injured by a round from our guns through a mistake in calculating firing data or in applying sight settings to the guns. The causes of such casualties were inherent hazards of the dangerous game of war; a fact that in no way diminished the devastated feelings of all involved. 103 Battery was able to maintain a good record. This was not only due to the depth of knowledge and training of all ranks, but also the dedication that I witnessed, time and again. These traits were manifested by a determination not to risk applying expedient solutions to difficult issues. The problems were there to be solved and we worked through them by applying ourselves to solutions based on application and adaption of the long-established orthodox practice which had been developed into our doctrine over generations.

\section{Sustaining the effort}

I lived on the gun position for 10 months of my tour. The unique fact of gun position life was that you were 'in action' for every hour and day of the tour. If Long Tan had taught us anything, it was that our state of readiness needed to be just as high at all times in the Nui Dat base as it was when deployed elsewhere. While the psychological pressure of being a gunner on the gun line was not the same level of that of a rifleman on patrol, 
it was constant - without relief. The only true rest for gun line soldiers was to get away from the gun position altogether - opportunities were rare. We lived cheek-by-jowl, night and day, and natural tensions could and did arise. That these were never allowed to impinge on required group performance is great tribute to the 'level-headedness' of all the NCOs and soldiers in the battery. I came to know and respect their profound talent to defuse occasions of raised tension. I well remember, on our penultimate day, when a 'stand-down' of four hours was declared so that we could relax as a total group. Within a few minutes of the call to take posts again, a three-battery 'fire mission regiment' was called and we were able to be first to report 'ready' one more time. They were truly a great team, and I will remember them always.

\section{Reflections by our medical assistant: Lance Corporal Brian 'Doc' Mortimer}

As the 103 Battery medic, one of my monthly duties was to participate in the medical civil aid program, or MEDCAP. A helicopter flew us to a village for a working session of around four hours, after which the helicopter would return us to base. For these village calls, I would take my basic medical pannier with me, enabling me to conduct an army-type sick parade for the villagers.

I would see around 30 people, treating basic health problems such as cuts, sore throats and minor local infections. Children would sometimes feign a sore throat so they could get lozenges. Those I determined needed to be reviewed by a medical officer would be seen later by the regimental medical officer (RMO), Captain John Taske, or his replacement, Captain Ted Heffernan.

On one of these MEDCAP visits, an old Vietnamese gentleman had a cyst the size of a tennis ball on his chest excised by the RMO, Captain Ted ('When-in-doubt, Cut-it-out') Heffernan without any local anaesthetic. Sutures were not available, so the village tailor provided cotton to close the wound. On subsequent visits, I found the patient to have healed very well. On another visit, some of us had the pleasure of being guests at a Vietnamese wedding. The wedding feast included plenty of meat, but as it was probably dog, routinely consumed in villages throughout Vietnam, I stuck with the rice and 'risky' salad. 
I recall our battery being deployed in support of 5 RAR in October 1966. We were located on Route 15, the main road to Saigon. It was a busy road and the guns were only metres from the traffic. Many buses would travel past, loaded with people, some strapped to the roof, along with produce and luggage. The traffic was nonstop until last light when a curfew came into effect. At stand-to one morning, I remember seeing in the half-light a lone figure on a bicycle. He was a local food vendor and his basket was loaded with the omnipresent, locally produced and everpopular fresh bread rolls. We affectionately called them 'heppo [hepatitis] rolls'. I can't recall how we paid for them as we never took money with us on operations.

I had been with the battery for nearly 12 months before I observed the guns firing on charge one (the lowest propellant charge) with the barrels almost vertical as the guns engaged a relatively nearby target which was masked by terrain. In this case the muzzle velocity of the round was so low I could see the blurred shape of the projectile leaving the gun.

Finally, a gruesome sight I will never forget was when we came upon makeshift shallow graves of about six VC soldiers. Due to the heat and build-up of decomposition gases, two of the corpses were observed sitting up in their graves.

\section{Operation Canberra, 6-10 October 1966: Captain Peter Aspinall}

When 103 Field Battery was allotted in direct support of 5 RAR, my FO Party and I were attached to B Company. We arrived in the B Company tent lines at Nui Dat on Sunday 28 August 1966, immediately following the completion of Operation Smithfield, the battlefield clearance operation after the Battle of Long Tan. I had been involved in both actions as the FO for A Company, 6 RAR.

On arrival in B Company lines, I met the officer commanding (OC), Major Bruce McQualter, with whom I was to form a close working relationship. This was key to ensuring the most effective use of close artillery support on operations. Initially, while in the Nui Dat lines, I shared a tent with his 2IC, Captain Bob O'Neill. During the company patrols that followed, 
I came to know the OC's patterns of thought, including what Bruce might want of close fire support by both artillery and strike aircraft. By the time of Operation Canberra, the understanding between us was instinctive.

In Operation Canberra, B Company was tasked to clear the western side of the Nui Thi Vai hill. A major feature of this hill was a steep spur line, or ridge, running from west to east up to the crest of the hill to a height of 467 metres. This spur was very steep in places, at times with a gradient of 1 in 2 or 1 in 3, and it was thickly covered by trees, vines and bushes. C Company was similarly tasked to clear an area further east of us.

On 6 October, B Company was transported by APCs along Route 15 to a point north of the village of Ap Ong Trinh Dp where we dismounted to commence our advance north to the western side of Nui Thi Vai. Initial progress was slow as we were moving through very marshy ground, at times wading in waist-deep water. My artillery task in this early phase was limited to map-registering potential defensive fire targets along our planned track and to our east, the anticipated direction from which we might be contacted by the enemy.

By mid to late morning on 8 October, C Company to our east had advanced to the southern slopes of Nui Thi Vai and contacted the enemy, resulting in a number of casualties requiring evacuation. This action heightened the expectation of Major McQualter that B Company was likely to make contact as we moved around the south-western spur of Nui Thi Vai and approached the main west-to-east spur line from the south.

Not only did this spur rise steeply from west to east, it had steep slopes either side of the ridgeline. This posed a major difficulty in planning defensive fire targets, as the minor variations in the trajectory of each round fired, inherent in all artillery fire, could result in rounds impacting below the crest, or carrying over the spur's crest, well into the next gully or re-entrant. This problem was exacerbated by our west-east spur lying almost at right angles to the bearing from the gun position. A graphic demonstration of this situation occurred during a later operation when the FO attached to another company endeavoured to engage a target on a similarly placed spur line. When he ordered 'fire for effect', some rounds cleared the top of the spur line, only to fall into another company's area.

By mid-afternoon B Company was climbing the southern slope of the spur with the intention of crossing to the northern side. Major McQualter halted the company and called me forward and told me that the leading 
platoon had detected a group of VC estimated to be around 30 strong. $\mathrm{He}$ was sending reconnaissance groups to confirm the location and strength of the $\mathrm{VC}$ and, as it appeared that they might be preparing to depart, he was also anxious to deploy the company as quickly as possible to attack and prevent them escaping.

He gave orders to his platoons for a company attack and, although I was extremely concerned about the likely fall of shot for the reasons outlined, I rapidly created a comprehensive fire plan and sent it to the gun position. As the platoons deployed, the company headquarters moved to a more advantageous location. However, in doing so we found ourselves among booby trap tripwires that the $\mathrm{VC}$ had set. It was remarkable that none were tripped. When Bruce was comfortable with his company's dispositions, he radioed his $\mathrm{CO}$, Lt Col John Warr, that he was about to commence the attack. But the $\mathrm{CO}$ ordered him to hold his position. After a delay the $\mathrm{CO}$ called off the attack. While I was located close to Bruce, I could not hear the CO's instructions; but the look of disbelief on Bruce's face was clear.

Though nothing was said, based on our close relationship, I was certain he was on the verge of ordering his platoons to attack anyway; and then advising the $\mathrm{CO}$ that it was too late to comply with his order to desist. McQualter's discipline prevailed and he ordered his platoons to withdraw. For a considerable time, his demeanour betrayed his frustration and disappointment, which he later conveyed to me after the company had harboured for the night.

The company headquarters had difficulty extricating itself from among the tripwires; however, it did so without incident. Once clear of the immediate vicinity of the enemy the area was comprehensively engaged with mortar and artillery fire, then with USAF airstrikes as described in Chapters 7 and 14. After these engagements, it was too late in the day for any followup action by B Company. The next day it was confirmed that any VC who might have survived the bombardment had left the area. Much damage had been done and important information, equipment and other materiel was recovered, along with evidence of significant enemy casualties.

5 RAR's task of securing a part of Route 15 by clearing the Nui Thi Vai hill feature had been successful. However, it was not the success that might have been achieved had Bruce McQualter bowed to what I think was his first instinct, to disobey his $\mathrm{CO}$. On the other hand, very recent intelligence from credible sources had been hand delivered to CO 5 RAR, 
by the Task Force HQ's intelligence officer. It revealed that the enemy strength was probably more than the 30 that B Company estimated to have been present. If this information was correct, the task was too big for a company attack in terrain where it would be extremely difficult for 5 RAR's other companies to move rapidly to B Company's assistance if it was needed.

\section{Operation Hayman: Captain George Bindley}

While Operation Hayman took place shortly after 5 RAR's operations in the Nui Thi Vai hills, the following narrative is included as a sequel to illustrate the tensions that can develop between commanders who are each intent on doing their job, often under considerable pressure and amid a host of complexities. These tensions, sometimes exacerbated by personality conflicts extending over a series of incidents, can result in a senior officer being relieved of his command in battle - as was the outcome here.

Operation Hayman started on 8 November with 5 RAR flying in to Long Son Island from a landing zone close to Lang Phuoc Hoa village on the mainland. Crucially for some, this was the first time 1 ATF Tactical HQ deployed away from Nui Dat. I was battery captain, 103 Field Battery RAA. We were located on the mainland, close to Lang Phuoc Hoa, in direct support of 5 RAR. Two days later I flew to the island to join 5 RAR's HQ and take over as acting battery commander.

I arrived at 5 RAR's HQ, located adjacent to the Task Force HQ, where I joined the CO, Lieutenant Colonel John Warr, and Major Stan Maizey, his operations officer. C Company, 6 RAR, commanded by Major Brian McFarlane, was deployed to provide local defence for the Task Force HQ complex. The Task Force HQ's Defence and Employment (D\&E) Platoon was also placed under McFarlane's command. 1 Field Regiment's Tactical HQ, under Lieutenant Colonel Cubis, was also making its first operational deployment, and was located with the Task Force HQ group.

During the night 10/11 November, the D\&E Platoon sergeant reported that there was a largish number of enemy to his front moving towards his position. Brian McFarlane decided to use guns rather than mortars to engage them. His FO, Captain Tony Wales of 161 Field Battery RNZA (Royal New Zealand Artillery), opened fire adjustment a safe distance 
away on a point previously recorded by US Army medium artillery that afternoon. I switched my set onto the battery radio net to monitor progress with the fire mission. With overhead fire, artillery rounds at the end of their trajectory are moving away from the force they are supporting. By contrast, if a target is between our own troops and the guns, as it was in this case, the noise of rounds heading straight for you can be unnerving. The sky was overcast with a low cloud base amplifying the roar of rounds approaching the target. An idea of the experience is provided by Brian McFarlane in his book We Band of Brothers - A True Australian Adventure Story:

The Sergeant gave me a clear indication of how much to drop the fire towards him and we did it, and again, and again. He told me that the fire was approaching the area where the enemy troops were and we agreed on a small drop in range and to 'Fire for Effect' ... by this time all those in the various headquarters and in my company were wishing they had dug deeper trenches as the noise of the rounds exploding on the rocky ground was horrendous and some shrapnel and bits of rock were whistling through the air but not too desperately for those of us who were used to such things. ${ }^{1}$

Soon after the fire mission started, I received a call from 1 Field Regiment's Tactical HQ duty officer. He said the CO was unhappy with how the mission was being controlled. I explained that it was normal observed fire, and control was the FO's responsibility. And, although the sound of incoming shells might be a bit uncomfortable, that too was normal. The mission continued with, of course, drop corrections for range, which took the point of impact further away from the HQ complex.

Then, shortly afterwards Lieutenant Colonel Cubis called me by field telephone: 'What net are you on?' 'Battery sir.' 'You bloody idiot, MET - Mike Echo Tango!' 'Oh, you mean met [meteorological data]. We are not using any. None is available.' 'Apply a drop correction of 200 metres [to the range between guns and target] and tell the FO I want to see him in the morning.' Still fuming, he hung up. I did not relay this message to Tony Wales. He had enough on his plate. I passed the 'meteorology' correction to the GPO, Lieutenant Mike Langley, and ordered clinometer laying to improve accuracy.

1 Brian McFarlane, We Band of Brothers - A True Australian Adventure Story, Brian W. McFarlane, Sydney, 2000, pp 309-10. 
Because the OT line (from the location of the observer, Tony Wales, calling for the fire to the target) was east to west and the guns were firing from the north, the 'met' correction effectively reduced the guns' range by 200 metres but had little effect on the real culprit which was the bearing the guns were laid on. The fire was still coming almost directly towards the headquarters agglomeration, and each OT drop correction made by Tony swung the line of fire east and closer to those headquarters. When satisfied with his fire adjustments, Tony Wales then ordered, 'fire for effect' and nothing happened! Then, on the battery radio net, the GPO reported, 'End of mission'. Tony had not ordered it, and I certainly didn't. I asked the GPO who had terminated the fire mission. He said that it was ordered by Colonel Cubis on the regimental radio net.

I told Colonel Warr, who was furious. Stan Maizey offered the battalion mortars, but Brian McFarlane declined, preferring the more accurate guns with such a close target. Being a mere bearer of bad news did not stop me getting a good ribbing from John Warr and Stan Maizey. Again, from his book, Brian McFarlane takes up the story from his end:

As soon as Tony Wales gave the order, 'Fire for Effect' on the artillery regimental net, another call was broadcast:

'This is 95 Alpha [Cubis]. STOP.' The guns did not fire.

Tony replied, 'My Foxhound Sunray [My infantry commander, Major McFarlane] wants to know why.'

'Because my Sunray says so.' replied Cubis's operator. ${ }^{2}$

Brian McFarlane's question had been ignored. He wondered how the $\mathrm{CO}$ of the regiment located at Task Force HQ could veto an order for fire from a forward company commander in contact with the enemy and, when asked to explain, refused to do so. The D\&E Platoon reported there was still enemy movement between where the last shell had fallen and themselves. McFarlane called Brigadier Jackson, whose HQ he was defending, and explained what was happening. He was told he would get his fire. His book records:

Again, Captain Wales ordered 'Fire.'

Again, 95 Alpha ordered 'STOP.'

2 McFarlane, We Band of Brothers, pp 309-310. Emphasis added. 
Again, McFarlane called the Brigadier and received the same assurance.

Again, Captain Wales ordered 'Fire.'

Nothing was heard from 95Alpha; and the guns fired. ${ }^{3}$

The reality of who was running the battle had apparently eluded Lieutenant Colonel Cubis. His intervention clearly implied a lack of confidence in the professional competence of his officers and an unwillingness to state it. He had a reputation for intervening in matters simply because he could. Others felt that, because he had been acknowledged for a good effort commanding the artillery support for the Battle of Long Tan, he believed that his pronouncements on artillery matters were incontestable, irrespective of their context, timing or effect perhaps a sad case of incipient egomania. Whatever the cause, his actions were both faulty and dangerous.

Next morning Brigadier Jackson asked Brian McFarlane to come and see him. The brigadier apologised for what had happened and said that Cubis had been relieved of his command and when asked by Brigadier Jackson why he had intervened, he argued that, in his professional opinion, the fire was unsafe. The brigadier was not persuaded. This was not the first time that Brigadier Jackson had intervened to stop Cubis from doing something strange.

Earlier, during Operation Canberra, Cubis visited the gun position and found its siting unsuitable. He ordered a move to a better site. However, he neglected to inform or liaise with the battery commander located with HQ 5 RAR so that the move could be coordinated with the battalion's operational needs. This naturally upset the CO of 5 RAR. At the time the battalion was in sporadic contact with the enemy in the hills, and the move left them without their dedicated fire support for the significant amount of time needed to relocate the guns. Leaving aside technical reasons for relocating the guns to a better site, Cubis's arbitrary and precipitate order caused immediate concern and anger, and ongoing doubts in the minds of 5 RAR. When questioned about his intervention without consulting 5 RAR, Cubis insisted the movement/deployment of the guns was his prerogative. He would not retreat from this belief and the disputation inevitably involved Brigadier Jackson.

3 Ibid. Emphasis added. 
A short time later, during Operation Robin, there had been an incident that could have been catastrophic. The ARVN had two M2A2 $105 \mathrm{~mm}$ howitzers in their compound at Phu My. During the night they were firing H\&I into the Nui Thi Via hills to their south-east, uncomfortably close to 5 RAR. Despite attempts to stop it, the fire continued. Cubis decided the solution was for 103 Battery to fire a few warning rounds at the Vietnamese gunners in their compound.

I was called to the battery $\mathrm{CP}$ and briefed by the GPO, Lieutenant John Griggs. The guns were laid on the target ready to fire, but the Phu My area had been declared a 'no fire zone'. The implications were very serious. A series of questions sprang to mind in rapid succession: What if we received counter-battery fire in return? What if we, the ARVN or local civilians took casualties? Would we be headline news? How could we explain to an investigation that, despite being given an order we knew to be a serious violation of rules by which we were bound, we had fired on friendly troops and civilians? How could I stop it happening?

It came to me that I had seen a similar situation before. The film Paths of Glory (1957), Stanley Kubrick's antiwar epic, has a scene where an angry general gives an order to an artillery battery commander to fire on his own trenches. The battery commander refuses to fire unless given a written order. The general, fearing the consequences of his action and being unable to deny responsibility, backs down. This was worth a try. I spoke to the 1 Field Regiment duty officer at Nui Dat and said that I would not fire unless I received a written order. As it was the middle of the night and I was in an unsecured, remote area, my request was clearly impossible to satisfy. The alarm was raised. Brigadier Jackson was called, stepped in and stopped the rot. Thank heavens.

Now, in Operation Hayman on Long Son Island and with such recollections in mind, I called Artillery Tactical HQ next morning to ask when Cubis wanted to see Tony Wales. I was told that he had returned to the mainland and was not available. Stan Maizey then handed me a message addressed to all 1 ATF units written in longhand and signed by Major Dick Hannigan, the task force operations officer. It concluded, 'Major McDermott, 2IC of $1^{\text {st }}$ Field Regiment, has assumed administrative command of the Regiment.'

It was Remembrance Day, 11 November 1966. I will never forget it! 
This text is taken from Vietnam Vanguard: The 5th Battalion's Approach to Counter-Insurgency, 1966, edited by Ron Boxall and Robert O'Neill, published 2020 by ANU Press, The Australian National University, Canberra, Australia.

doi.org/10.22459/VV.2019.12 